\title{
ACTA GENETICAE MEDICAE ET GEMELLOLOGIAE ENTERING ITS THIRD DECADE
}

\author{
EDITORIAL
}

The first issue of Acta Geneticae Medicae et Gemellologiae was published in January I 952 .

Our journal has therefore been present in the field of Medical Genetics and Twin Research for twenty years now. This presence has been witnessed by the publication of three issues a year from 1952 through 1956 , while from 1957 onwards the increasing amount of papers and of interest from the readers made it become a quarterly. A number of special issues and supplements have also been published.

The present is in fact a special double issue: it is intended to celebrate the entrance of Acta into its third decade of existence; moreover, it is also intended to inform our readers of a new initiative - the foundation of a new Medical Genetics and Twin Research Institute in Jerusalem, on the Mount of Olives.

Our journal has had the privilege of coming to life and lively exist in a period which has witnessed the tremendous explosion of biomedical knowledge, largely due to the addition of the molecular model to the statistical-empirical model on which Genetics has been built up.

Acta characteristically endeavored to apply Genetics to a better knowledge of the diseased man, thus contributing to that remarkable effort Medicine has been undertaking in order to modify itself on account of the hereditary parameter an effort which actually represents a pacific revolution, pathology having thereby been entirely transformed, both on the general and the clinical plane. In this perspective, numerous and important contributions have been published, concerning the various aspects of modern medicine.

Among the peculiarities characterizing the over Io,00o pages published so far by our journal, the main one clearly appears from the term, Gemellology, in its title, which means twin research. Acta is in fact the first and only periodical especially devoted to twin studies, and authors from all over the world refer to it for their publications. Only on its regular issues (and therefore excluding all supplements), 
in a total of over $1,000,316$ papers devoted to twin research have been published, distributed by country of origin as follows:

EUROPE

Italy

W. Germany

Great Britain

Holland

Belgium

France

Sweden

Denmark

Switzerland

Cizechoslovakia

Rumania

Bulgaria

Austria

Hungary

Norway

Soviet Union

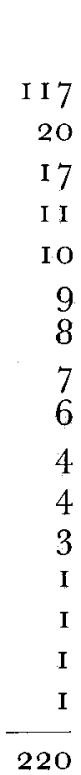

America

USA

Canada

$5^{6}$

Brazil

$-\frac{23}{84}$

Asia

India

Japan

4

Israel

Africi

Nigeria

International Organizations

Early in I970, Acta devoted a special double issue to the publication of the full Proceedings of the First International Symposium on Twin Studies, held in Rome on 4-7 September I969 ("Advances in Twin Studies", Acta Genet. Med. Gemellol., I9: I-2).

Of course, medical- and human-genetic problems were dealt with, not only with the twin method, but more at large and with any other approach. Moreover, Acta has also been following with interest new trends of genetic studies, mainly introduced and applied at the Mendel Institute in Rome, referred to as Chronogenetics, i.e., the heredity of biological time. Here is in fact a new subject of great interest in that it introduces a dynamic, developmental perspective in the observation of genetic phenomena, otherwise bound to the Mendelian and/or the molecular perspective, both static in nature. From the very beginning of these studies, over ten years ago, through the more recent developments, witnessed by the Round Table, Chronology of the Gene, within the Fourth International Congress of Human Genetics (Paris, 6-I I September I97I), Acta has appeared as the natural seat for the publication and discussion of papers on the subject. 
More and more care has been devoted to editorial and technical aspects. New authoritative names have joined the Editorial Board, while unfortunately the latter had to suffer the loss of eminent colleagues, great masters and friends, such as Caullery, Dahlberg, Ford-Walker, Franceschetti, Gesell, Kallmanı, Kemp, Newman, Schwesinger, von Verschuer, and others. While keeping unaltered Acta's main peculiarities, which largely contributed to its noted character of refinement, considerable efforts have been made towards better standardization and compliance with international editorial recommendations. Also, while continuing to use all four languages, English, Italian, French, and German, for the index of contents and the summaries, and continuing to accept papers in either of the four, the use of the English language on the part of the authors is being encouraged while it has been generalized in the editorial practice.

So, summing up, it is with some satisfaction and great hopes that Acta now enters its third decade of life. And with a sense of gratefulness too: authors, subscribers and occasional readers, members of the Board, consultants and cooperators, individuals and institutions - all should be thanked for their constant interest and precious contribution.

When Acta was first published, in I952, works had already begun for the building of an institution which, just like the journal, would be devoted to medical genetics and twin research. The Gregor Mendel Institute of Medical Genetics and Twin Studies - now the publisher of Acta -- was in fact inaugurated early in I 953.

Twenty years later, now that Acta is entering its third decade, we are happy to announce that works have begun for the building of a second institute, similar in scope and extent to the Mendel Institute. The new institute is being built in Jerusalem, on the Mount of Olives - a location from which it dominates the whole of the sacred town.

The cornerstone was laid on 28 March I972. The ceremony was attended by the representatives of the Town of Jerusalem, of the Israel Ministry of Health, as well as by religious and civil authorities and by leading Israeli scientists. In turn, some fifty university professors, scientists, and laymen had come from all over Italy for that occasion. The ceremony was then followed by a reception at the Israel Museum offered by the Minister of Justice, Mr. Shapiro, in the name of the Governement of Israel.

The addresses given on that occasion are reproduced in the following pages, together with a photographic account of the whole ceremony.

On the formal plane, the institute is inspired to the local architecture and the surrounding, unique landscape of the Mount of Olives, in which it wants to fit completely, in full respect of the traditions and sacred character of Jerusalem and the very place on which it shall be built. 
On the structural plane, it shall be built largely on the same model of the Mendel Institute in Rome and with the same goals, i.e., give free and specialized medical, psychological, and social assistance to all twins, and start and develop a twin register to be used for research purposes. To the medical clinics, specialized genetic laboratories, lecture halls, library, and residence for foreign scientists shall be added.

The foundation of this new institute in Jerusalem celebrates not only the twenty years of Acta, which have already been completed, but also the twenty years of the Mendel Institute, to be completed in r 973 .

In these twenty years, scientists from all over the world have taken active part to the life of Acta as well as to the life of the Mendel Institute, where thousands of them have come for a visit, and many have stayed and worked with us for some time. We are confident that the Jerusalem institute will continue and enhance this tradition.

LUIGI GEDDA

Rome, I4 June I972 